\title{
The Effect of Mobbing on Burnout Syndrome at Workplace: An Application on Health Staff in Turkey
}

\author{
Ayça Hatice TÜRKAN \\ Afyon Kocatepe University, \\ Department of Statistics, \\ Afyonkarahisar 03200, Turkey \\ aturkan@aku.edu.tr
}

\author{
İbrahim KILIÇ \\ Afyon Kocatepe University, \\ Department of Biostatistics, \\ Afyonkarahisar 03200, Turkey \\ kilicibrahim@hotmail.com
}

\begin{abstract}
People feel themselves inadequte, desperate and have problem of social isolation as a result of mobbing and occupational burnout in working places. Thus it threats life, health and productivity of people. Mobbing and occupational burnout are common problems in health sector. The aim of this study was to determine the levels of mobbing and occupational burnout of health staff and to reveal the influence of mobbing on occupational burnout. As the way of collecting data, a questionnaire consisting of Leymann and Maslach scales was used. The data were analysed using descriptive statistics, correlation and regression analysis.
\end{abstract}

Keywords: Health staff, Mobbing, Occupational Burnout.

\section{Introduction}

\subsection{The Concept of Mobbing}

In early 1980s, Leymann used the term of mobbing for a specific child behaviour which had been used by Konrad for a particular animal behaviour and used by Heinemann (1972) to identify similar types of behaviour at workplaces (Lorenz, 1991; Leymann, 1996). Leymann prefers to use the term of mobbing instead of bullying used extensively for the same purpose in the literature. He used the term of bullying in activities among children and teenage children because the term of bullying at school includes physically aggressive acts whereas mobbing behaviour at workplace rarely involves physical violence according to him. However, we can see that the terms of mobbing and bullying are used for the same purpose in the literature (Rayner, \& Hoel, 1997; Zapf, 1999; Quine, 2001; Vartia, 2001).

Mobbing at the workplace means hostile and unethical communication in a systematic way to an individual directed by one or a group of people (Leymann, 1996). Mobbing, referred in such words "harassing", "ganging up on someone" or "psychologically terror" in the studies of Leymann $(1990 ; 1996)$ poses a major threat to the physical and mental health at workplaces because of psychical, social, and psychosomatic effects (Vartia, 2001). And unfortunately mobbing is so extremely 
widespread in today's environment that it is impossible not to witness any kind of mobbing.

In the study of Leymann (1988) the person in the schism is defined as a victim (Leymann, 1990). Leymann (1996) subdivided the behaviors of mobbing witnessed by the victim into five categories with the help of interviews. Preventing communication, social isolation, spreading rumors, affecting occupational situation and affecting physical health of victim can be listed for behavior types. Leymann (1990) explained the structure of critical events of mobbing process respectively. This process includes four phases which are called as "original critical incident", "mobbing and stigmatizing", "personel administration" and "expulsion".

The causes, importance, properties, consequences of mobbing and ways of prevention from it have been the subjects of many studies relying on interviews, questionnaire surveys and observations.

Zapf et al. (1996) considered the relationship between mobbing, job characteristics, social environment variables, and psychological ill-health. Also, they distinguished seven mobbing factors by using the Leymann Inventory of Psychological Terrorization (LIPT): mobbing by organizational measures, social isolation, attacking the victim's private life, attacking the victim's attitudes, physical violence, verbal aggression, and rumours. And then Zapf (1999) investigated causes of mobbing at work by using several scales. In this study, organization and perpetrator as well as social system and victim are set forth as the causes of mobbing. Additionally, Zapf (1999) allows us to examine the cause and effect relationship related to mobbing.

Hubert and Van Veldhoven (2001) emphasized that there are large differences in the occurrence of undesirable behaviour between sectors. They used the Questionnaire on the Assessment and Experience of Work (Vragenlijst Beleving en Beoordeling van de Arbeid; VBBA; van Veldhoven \& Meijman, 1994) in their study. Quine (2001) categorized bullying into five categories: threat to professional status, threat to personal standing, isolation, overwork, and destabilization. Also in this study correlations between categories of bullying and occupational health outcomes (job satisfaction, anxiety, depression, propensity to leave) were presented. Vartia (2001) revealed that mobbing at workplaces has negative effects not only on the victims' welfare but also on witnesses' welfare. Vartia (2001) investigated the relationship between the hostile behaviours detected by the Leymann Inventory and such factors as general stress, mental stress reactions and feelings of low self-confidence.

Çobanoğlu (2005) reported the causes of mobbing related to the health sector, in Turkey. These causes were listed as follows: lack of medical facilities in hospitals; excessive working time due to large number of patients; low wage; bureaucratic obstacles; discrimination in the workplace; becoming family life more difficult due to excessive working time; failure to performing (fulfil) the requirements of the profession; discrimination among patients.

Demirel and Yoldaş (2008) examined whether the five sub-dimensions of mobbing behaviours determined by Leymann Inventory show differences in Turkey and Kazakhstan. They found that there are statistically significiant differences between two countries with regard to five structures of mobbing behaviours and mobbing behaviours are seen more in health care workers in Kazakhstan. Yildırım and Uysaloğlu (2012) 
explored the impact of demographic factors and job position on employees' mobbing perception. Aydan et al. (2012) aimed to identify both demographic characteristics of victims and perpetrators and mobbing behaviours of perpetrators in private education institutions. For this purpose they used mobbing behaviours amongst primary education institutions survey. Cogenli and Barl1 (2013) made an application to the Academicians using Leymann Inventory of Psychological Terror. Also, Faria et al. (2012) and Celep and Konaklı (2013) dealt with mobbing in education sector.

Cornoiu and Gyorgy (2013) described hostile action types of mobbing and its causes and effects. Topa and Moriano (2013) examined the relationships between work stress, group support, and group identity with horizontal mobbing in the sector of health care. They found that stress is positively associated to horizontal mobbing, whereas group support and group identity are negative predictors of horizontal mobbing.

Soysal et al. (2014) investigated whether five sub-dimensions of mobbing behaviours determined by Leymann show any differences with regard to gender.

\subsection{The Concept of Burnout}

Burnout began to be used in the 1970s. Maslach and Jackson (1981) defined "burnout" as a syndrome of emotional exhaustion and cynicism that occurs frequently among individuals who do 'people-work' of some kind. Maslach and Jackson (1981) developed the Maslach Burnout Inventory (MBI) to evaluate the dimensions of burnout and to meet the need for an instrument to assess burnout. Maslach and her colleagues emphasize a multidimensional model for burnout and they define its dimensions as cynicism, exhaustion and feelings of inefficacy. Maslach (2003) indicates that the relationship between exhaustion and cynicism is clearer while it is vague between feelings of inefficacy and the other two dimensions because the exhaustion and cynicism can emerge from the same reasons (e.g., work overload or social conflict). However, the reasons of inefficacy feelings (e.g., lack of information or insufficient time) are different from others. Sometimes feelings of inefficacy can rise as a result of the other two dimensions (Maslach, 2003). Thus, both Maslach and her colleagues' studies and Maslach Burnout Inventory have inspired a lot of studies in Turkey and abroad in many sectors.

Naude and Rothmann (2004) used Maslach Burnout Inventory-Human Services Survey (MBI-HSS), a version of MBI, developed for emergency medical technicians. They used principal components analysis to determine the factors of MBI-HSS. MBIHSS was designed in such a way that it contains three subscales, namely emotional exhaustion, depersonalisation and personal accomplishment. Borritz et al. (2006) tested the MBI but they didn't obtain satisfactory results and in order to measure burnout, they developed their own instrument, Copenhagen Burnout Inventory (CBI). As they wanted to focus on exhaustion, their inventory is based on three types of exhaustion: personal burnout (including general symptoms of exhaustion), work-related burnout and clientrelated burnout. Through this study, burnout was given in a different theoretical framework.

D'Alleo and Santangelo (2011) aimed to describe the levels of burnout in call center operators and the organizational climate of the companies. In addition they wanted to test the relationship between dimensions of organizational climate and the burnout syndrome in call centers by using the MBI and the Questionnaire for the 


\section{A. H. Türkan - İ. Kılıç 7/3 (2015) 7-21}

Analysis of Organizational Climate. Sadeghi and Khezrlou (2014) compared the levels of teachers' burnout in terms of age, gender, marital status, and level of education by using MBI in their research whose participants consist of English Language Teachers in Iran.

\subsection{The Relationship between Mobbing and Burnout}

At the workplaces where the victims are suffering from mobbing, emotional, physical, and psychological exhaustion, known as burnout can be observed, too. Many studies in the literature include the relationship between mobbing and burnout. In the following, a short review of some of these studies will be presented.

Einarsen et al. (1998) confirmed that there is a significant relationship between mobbing and burnout among health care professionals. They reported that the nurses exposed to bullying at work have significantly higher levels of burnout. They also revealed that the nurses exposed to bullying have significantly higher levels of burnout, lower job-satisfaction and lowered psychological well-being compared to nurses not exposed to bullying.

Alkan et al. (2011) examined the relationships between mobbing and burnout and also between their sub-dimensions for physical education and sports teachers. Tanhan and Çam (2011) determined the relationship between mobbing and burnout, and also between mobbing and dimensions of burnout which are emotional exhaustion, depersonalisation and personal accomplishment for teachers.

Dikmetaş et al. (2011) explained the relationship between the levels of mobbing and burnout of physician assistants. The aim of this study was to determine whether individual characteristics have effects on levels of mobbing and burnout. They explained the effect of mobbing and two sub-dimensions of burnout on third subdimension left.

Laschinger et al. (2012) demonstrated a model including authentic leadership, workplace bullying, emotional exhaustion, job satisfaction and turnover intentions with the help of Path Analysis Techniques. In this study on nurses, the subscale of MBI was used to measure the level of emotional exhaustion. And also they used Negative Acts Questionnaire-Revised (Einarsen \& Hoel, 2001) to measure mobbing behaviours.

Karakuş and Çankaya (2012) determined that mobbing has positive effect on stress and burnout and has negative effect on job and life satisfaction in a population of primary school teachers. They used exploratory factor analysis followed by confirmatory factor analysis to obtain these results.

Kozak et al. (2013) examined the effects of job-related psychosocial aspects and outcomes like mobbing on personal burnout. They indicated a high positive correlation between personal burnout and mobbing.

The aim of this study was to determine the levels of mobbing and occupational burnout of health staff and to reveal the influence of mobbing on occupational burnout. In this context, the basic hypothesis of research can be expressed as follows:

Hypothesis: The frequency of mobbing behaviours in health staff has a crucial influence on the level of occupational burnout. 


\section{Method}

\subsection{Collection of Data}

Questionnaire was used as the data collection technique. Face to face interviewing was performed by researchers. This questionnaire consists of three parts. The first part contains information about the participants (involving gender, marital status, age range, occupation, institutions, length of service). The second part contains a scale developed by Leymann $(1990,1996)$ for assessing the types of mobbing. This scale called Leymann Inventory Psychological Terrorization (LIPT) consists of 45 5-point Likert type questions. These 45-items were designed by Leymann to measure five constructs of mobbing behaviours: Behavior threatening communication (items 1-11), Behavior threatening social contacts (items 12-16), Behavior threatening personal reputation (items 17-31), Behavior threatening occupational situation (items 32-40), Behavior threatening physical health (items 41-45). Responses related to the frequency of hostile behaviours were rated on a Likert scale ranging from 1 to 5. (1: never, 5: always). The third part of questionnaire contains Maslach Burnout Inventory (MBI) of Maslach and Jackson (1981). It comprises 22 items including three factors as follows: emotional exhaustion (items 1-9), reduced sense of personal accomplishment (items 10-17), depersonalization (items 18-22). These items were rated using a five-level Likert scale ranging from 1 to 5. (1: never, 5: always).

\subsection{Population and Samples}

The participants of the study are doctors, nurses and other health staffs (laboratory assistant, medical technicians, etc.) working in private hospitals, state hospitals, university hospitals and other health centers (family physicians, polyclinics, etc.) in Afyonkarahisar, Kütahya and Isparta, Turkey. In this study, sampling was performed for saving time and cost. In this framework, stratified sampling was used and types of hospital (private hospitals, state hospitals, university hospitals and other health centers) were determined as strata. Sample size was calculated by formula $\left(n=s^{2} Z_{\alpha}^{2} / d^{2}\right)$ recommended by NEA (1965) for quantitative research and infinite universe $(N>10$ 000). According to the formula, minimum acceptable sample size was found to be 465 $\left(\mathrm{s}=1.10, \mathrm{Z}_{\mathrm{a}}=1.96, \mathrm{~d}=0.10\right.$; $\mathrm{s}$ : standard deviation, $\mathrm{Z}_{\mathrm{a}}$ : critical or theorical table value for significant level " 0.050 ", d: effect size). The questionnaires were handed out to 600 members of health staff. However, a total of 517 questionnaires were included in the analysis by omitting 83 questionnaires that were not responded or responded incompletely.

\subsection{Data Analysis}

To analyze the data obtained by survey method, SPSS was used. Table 1 provides descriptive statistics of the sample. First, the means and standard deviations of scores of mobbing and burnout were obtained. Second, factor analysis and reliability analsis were employed to confirm the validity of the responses to questionnaires. Moreover, Independent Samples T Test and One Way ANOVA were performed in order to compare hostile actions faced by participants and levels of burnout experienced by participants in terms of the individual characteristics of them.

In this sudy, correlation and regression analysis were run to determine the relationship between mobbing and occupational burnout. 


\section{A. H. Türkan - İ. Kılıç 7/3 (2015) 7-21}

The results are described in the next Section.

\section{Results}

In Table 1, the distribution of the participants working in health institutions is presented in terms of demographic properties. The results reveal that $55.9 \%$ of the participants are female, $62.9 \%$ of them are married, $82.2 \%$ of them are 38 years or younger, and $80.3 \%$ of them are working for ten years or less. Of the whole sample $17.6 \%$ are doctors, $45.1 \%$ are nurses, and $37.3 \%$ are other health staff (including laboratory assistant, medical technicians, etc.). As their working places considered, $48.9 \%$ are the employees in private hospitals, $18.2 \%$ are in state hospitals, $13.5 \%$ are in university hospitals, and $19.3 \%$ are in other health institutions.

Table 1. Distribution Of the Participants' Demographic Properties

\begin{tabular}{llrr}
\hline Variables & Groups & Frequencies & Percent \\
\hline Gender & Female & 289 & 55.9 \\
& Male & 228 & 44.1 \\
\hline Marital Status & Single & 192 & 37.1 \\
& Married & 325 & 62.9 \\
\hline Age range & $18-28$ & 185 & 35.8 \\
& $28-38$ & 240 & 46.4 \\
& $38-48$ & 57 & 11.0 \\
& $48-58$ & 21 & 4.1 \\
Occupation & $58-65$ & 14 & 2.7 \\
\hline Institutions & Doctor & 91 & 17.6 \\
& Nurse & 233 & 45.1 \\
& Other & 193 & 37.3 \\
\hline Length of service & Private & 253 & 48.9 \\
& State & 94 & 18.2 \\
& University & 70 & 13.5 \\
& Other & 100 & 19.3 \\
\hline TOTAL & $0-5$ & 289 & 55.9 \\
& $5-10$ & 126 & 24.4 \\
& $10-15$ & 39 & 7.5 \\
& $15-20$ & 31 & 6.0 \\
& 20 years & 32 & 6.2 \\
\hline
\end{tabular}

Table 2 demonstrates the results of factor analysis and reliability analysis conducted to support the structral validity of inventories. According to this table, the number of factors whose eigenvalues are greater than 1 is 5 in Leymann Inventory and 3 in Maslach Inventory. Furthermore, it was found that the mean score of mobbing (1.75) is lower than the mean score of occupational burnout (2.49).

In Leymann Inventory, the third factor "behavior threatening personal reputation" explained the $23.7 \%$ of the variance and made a major contribution. Following the third factor, the fourth factor (behavior threatening occupational situation) and the first factor (behavior threatening communication) had also great contribution in explaining the variance. However, a decrease was observed in the second and the fifth factors. The 


\section{A. H. Türkan - İ. Kılıç 7/3 (2015) 7-21}

total contribution of these five factors to variance was $75.0 \%$. Cronbach alpha coefficients were calculated as greater than 0.90 for all factors. As means scores of the factors were investigated, it was seen that the values changed between 1.53 and 1.87. This revealed that the means of mobbing behaviours were lower than middle-level. Mean scores had the highest value in the dimension of "behavior threatening personal reputation" (1.85) and the lowest value in the dimension of "behavior threatening occupational situation" (1.53).

The first factor "emotional exhaustion "explained the $25.8 \%$ of the variance in Maslach Inventory. This made a great contribution to the variance. As regards the quantity provided to variance, the second factor "reduced sense of personal accomplishment", and the third factor "depersonalization" came after the first factor. Cronbach alpha coefficients were calculated as greater than 0.80 for all factors. As means scores of the factors were examined, it was found that the values changed between 2.32 and 2.61. According these values, it could be concluded that the burnout levels of health staff were lower than middle-level. Mean scores had the highest value in the dimension of "emotional exhaustion" (2.61) and the lowest value in the dimension of "reduced sense of personal accomplishment" (2.32).

Table 2. The Results of Factor Analysis and Reliability Analysis

\begin{tabular}{|c|c|c|c|c|c|c|}
\hline Factors & $\begin{array}{l}\text { Number } \\
\text { of Items }\end{array}$ & $\begin{array}{l}\text { Eigen- } \\
\text { values }\end{array}$ & $\begin{array}{c}\text { Variance } \\
\text { explained } \\
\%\end{array}$ & $\begin{array}{c}\text { Cronbach's } \\
\text { Alpha }\end{array}$ & $\overline{\mathrm{X}}$ & SD \\
\hline $\begin{array}{l}\text { M1: Behavior } \\
\text { threatening } \\
\text { communication }\end{array}$ & 11 & 6.78 & 15.1 & 0.93 & 1.87 & 0.81 \\
\hline $\begin{array}{l}\text { M2: Behavior } \\
\text { threatening social } \\
\text { contacts }\end{array}$ & 5 & 4.15 & 9.2 & 0.94 & 1.60 & 0.91 \\
\hline $\begin{array}{l}\text { M3: Behavior } \\
\text { threatening personal } \\
\text { reputation }\end{array}$ & 15 & 10.68 & 23.7 & 0.95 & 1.85 & 0.83 \\
\hline $\begin{array}{l}\text { M4: Behavior } \\
\text { threatening occupational } \\
\text { situation }\end{array}$ & 9 & 7.85 & 17.4 & 0.95 & 1.53 & 0.84 \\
\hline $\begin{array}{l}\text { M5: Behavior } \\
\text { threatening physical } \\
\text { health }\end{array}$ & 5 & 4.31 & 9.6 & 0.95 & 1.76 & 1.03 \\
\hline Total scores of mobbing & 45 & - & 75.0 & 0.93 & 1.75 & 0.51 \\
\hline $\begin{array}{l}\text { OB1: Emotional } \\
\text { Exhaustion }\end{array}$ & 9 & 5.69 & 25.8 & 0.92 & 2.61 & 0.89 \\
\hline $\begin{array}{l}\text { OB2: Reduced Sense of } \\
\text { Personal } \\
\text { Accomplishment }\end{array}$ & 8 & 4.46 & 20.2 & 0.88 & 2.32 & 0.78 \\
\hline OB3: Depersonalization & 5 & 3.46 & 15.7 & 0.89 & 2.54 & 0.96 \\
\hline Total scores of burnout & 22 & - & 61.7 & 0.87 & 2.49 & 0.58 \\
\hline
\end{tabular}

Findings about the comparison of levels of mobbing and occupational burnout of health staff in terms of personal characteristics are shown in Table 3 . The findings indicated there is a statistically significiant difference among the institutions and length of services with regard to levels of mobbing and occupational burnout. The results 


\section{A. H. Türkan - İ. Kılıç 7/3 (2015) 7-21}

yielded that marital status had an influence on levels of mobbing and gender and occupation had an effect on the levels of occupational burnout. The levels of mobbing was higher in single $(\overline{\mathrm{X}}=1.84)$ compared to married $(\overline{\mathrm{X}}=1.69)$, employees working in state hospital $(\overline{\mathrm{X}}=1.86)$ and university hospital $(\overline{\mathrm{X}}=1.81)$ compared to the other health institutions, employees working less than five years $(\overline{\mathrm{X}}=1.81)$ compared to the others. The levels of occupational burnout was higher in females $(\bar{X}=2.54)$ than males $(\bar{X}=2.41)$, nurses $(\bar{X}=2.57)$ than doctors $(\bar{X}=2.37)$, employees working between 0 to 5 years $(\bar{X}=2.56)$ than the ones working more than 5 years, employees working in university hospital $(\bar{X}=2.73)$ than other health institutions.

Table 3. Comparison of Means of Mobbing and Occupational Burnout Levels with Regard to Participants' Demographic Characteristics

\begin{tabular}{|c|c|c|c|c|c|c|c|}
\hline \multirow{2}{*}{ Variables } & \multirow{2}{*}{ Groups } & \multicolumn{3}{|c|}{ Mobbing } & \multicolumn{3}{|c|}{ Burnout } \\
\hline & & $\bar{X}$ & $\mathrm{SD}$ & $\mathrm{p}$ & $\bar{X}$ & SD & $\mathrm{P}$ \\
\hline \multirow[t]{2}{*}{ Gender } & Female & 1.76 & 0.50 & \multirow{2}{*}{0.576} & 2.54 & 0.57 & \multirow{2}{*}{$0.017^{*}$} \\
\hline & Male & 1.73 & 0.53 & & 2.41 & 0.58 & \\
\hline \multirow[t]{2}{*}{ Marital Status } & Single & 1.84 & 0.54 & \multirow{2}{*}{$0.020^{*}$} & 2.53 & 0.51 & \multirow{2}{*}{0.176} \\
\hline & Married & 1.69 & 0.48 & & 2.46 & 0.61 & \\
\hline \multirow[t]{5}{*}{ Age range } & $18-28$ & 1.81 & 0.50 & \multirow{5}{*}{0.310} & 2.52 & 0.53 & \multirow{5}{*}{0.200} \\
\hline & $28-38$ & 1.72 & 0.52 & & 2.50 & 0.56 & \\
\hline & $38-48$ & 1.68 & 0.53 & & 2.42 & 0.69 & \\
\hline & $48-58$ & 1.68 & 0.58 & & 2.25 & 0.67 & \\
\hline & $>58$ & 1.69 & 0.33 & & 2.33 & 0.60 & \\
\hline \multirow[t]{3}{*}{ Occupation } & Doctor & 1.76 & 0.55 & \multirow{3}{*}{0.676} & $2.37 \mathrm{~b}$ & 0.72 & \multirow{3}{*}{$0.007^{* *}$} \\
\hline & Nurse & 1.76 & 0.50 & & $2.57 \mathrm{a}$ & 0.50 & \\
\hline & Other & 1.72 & 0.50 & & $\begin{array}{c}2.43 \\
a b\end{array}$ & 0.57 & \\
\hline \multirow[t]{4}{*}{ Institution } & Private & $1.71 \mathrm{~b}$ & 0.48 & \multirow{4}{*}{$0.028^{*}$} & $2.40 \mathrm{~b}$ & 0.56 & \multirow{4}{*}{$0.000^{* * *}$} \\
\hline & State & $1.86 \mathrm{a}$ & 0.58 & & $2.50 \mathrm{~b}$ & 0.53 & \\
\hline & University & $1.81 \mathrm{a}$ & 0.51 & & $2.73 \mathrm{a}$ & 0.51 & \\
\hline & Other & $1.67 \mathrm{~b}$ & 0.48 & & $2.42 \mathrm{~b}$ & 0.63 & \\
\hline \multirow[t]{5}{*}{ Length of service } & $0-5$ & $1.81 \mathrm{a}$ & 0.53 & \multirow{5}{*}{$0.022^{*}$} & $2.56 \mathrm{a}$ & 0.54 & \multirow{5}{*}{$0.001^{* *}$} \\
\hline & $5-10$ & $1.66 \mathrm{~b}$ & 0.45 & & $2.45 \mathrm{~b}$ & 0.54 & \\
\hline & $10-15$ & $1.63 \mathrm{~b}$ & 0.44 & & $2.40 \mathrm{~b}$ & 0.75 & \\
\hline & $15-20$ & $1.67 \mathrm{~b}$ & 0.48 & & $2.38 \mathrm{~b}$ & 0.56 & \\
\hline & $>20$ & $1.68 \mathrm{~b}$ & 0.55 & & $2.13 \mathrm{c}$ & 0.60 & \\
\hline
\end{tabular}

${ }_{p}^{*}<0.050 \quad{ }^{* *} p<0.010 \quad{ }^{* * *} p<0.001 \quad a, b, c$; The difference between groups having different letters is significant.

The simple linear regression analysis was carried out to reveal the effect of mobbing on occupational burnout. Its results are presented in Table 4 . The multiple linear regression analysis was conducted to display the effect of mobbing on subdimensions of occupational burnout. The results are demonstrated in Table 5.

As seen in Table 4, the model including mobbing (M) and occupational burnout $(\mathrm{OB})$ is significant $(\mathrm{F}=172.72 ; \mathrm{p}<0.001)$. The $\mathrm{R}$ square of this regression model was found 0.25 . This means that mobbing explained $25 \%$ of the variance in occupational burnout. The model obtained as a result of simple linear regression analysis is exhibited as follows.

$$
\mathrm{OB}=1.50+0.56 \mathrm{M}
$$




\section{A. H. Türkan - İ. Kılıç 7/3 (2015) 7-21}

According to the model, an increase in mobbing led to an increase in the value of 0.56 in occupational burnout. There is moderate positive correlation between mobbing and occupational burnout $(\mathrm{r}=0.50)$. It means that the levels of occupational burnout increase when the levels of mobbing increase, or vice versa.

Table 4. The Regression Model between Mobbing and Occupational Burnout

\begin{tabular}{lccccccc}
\hline Model & $\boldsymbol{\beta}_{\mathbf{i}}$ & $\mathbf{S E}$ & $\mathbf{t}$ & $\mathbf{p}$ & $\mathbf{R}$ & $\mathbf{R}^{2}$ & ANOVA \\
\hline Constant & 1.50 & 0.08 & 19.19 & $0.000^{*}$ & & & $\mathrm{~F}=172.72$ \\
Mobbing & 0.56 & 0.04 & 13.14 & $0.000^{*}$ & & & $\mathrm{p}=0.000^{*}$ \\
\hline
\end{tabular}

Dependent variable: Occupational burnout $\quad{ }^{*} p<0.001$

As seen in Table 5, the model including sub-dimensions of mobbing (M1, M2, M3, M4, M5) and occupational burnout $(\mathrm{OB})$ is significant $(\mathrm{F}=46.70 ; \mathrm{p}<0.001)$. The $\mathrm{R}$ square of this regression model was found 0.31 . This means that sub-dimensions of mobbing explained $31 \%$ of the variance in occupational burnout.

As stated in the results of regression analysis, all sub-dimensions of mobbing were necessary for this model except "behavior threatening occupational situation". The sub-dimensions of mobbing were ranged starting from the highest to lowest with respect to influence on occupational burnout as follows "behavior threatening personal reputation", "behavior threatening communication", "behavior threatening physical health", and "behavior threatening social contacts". The model obtained as a result of multiple linear regression analysis is exhibited as follows.

$$
\mathrm{OB}=1.41+0.16 \mathrm{M} 1+0.13 \mathrm{M} 2+0.20 \mathrm{M} 3+0.14 \mathrm{M} 5
$$

According to the model, an increase in the sub-dimension of mobbing which had the highest effect on the occupational burnout led to an increase in the value of 0.20 in occupational burnout.

Table 5. The Regression Model between Mobbing and The Sub-Dimensions of Occupational Burnout

\begin{tabular}{lllllll}
\hline Model & $\boldsymbol{\beta}_{\mathbf{i}}$ & $\mathbf{S E}$ & $\mathbf{t}$ & $\mathbf{p}$ & $\mathbf{R}^{2}$ & ANOVA \\
\hline Constant & 1.41 & 0.08 & 18.34 & $0.000^{*}$ & & \\
M1 & 0.16 & 0.03 & 5.51 & $0.000^{*}$ & & \\
M2 & 0.13 & 0.03 & 4.88 & $0.000^{*}$ & 0.31 & $\mathrm{~F}=46.70$ \\
M3 & 0.20 & 0.03 & 6.98 & $0.000^{*}$ & & $\mathrm{p}=0.000^{*}$ \\
M4 & 0.02 & 0.03 & 0.76 & 0.446 & & \\
M5 & 0.14 & 0.02 & 6.66 & $0.000^{*}$ & & \\
\hline
\end{tabular}

Dependent variable: Occupational burnout $\quad{ }^{*}<0.001 \quad$ M1: Behavior threatening communication; M2: Behavior threatening social contacts; M3: Behavior threatening personal 
reputation; M4: Behavior threatening occupational situation; M5: Behavior threatening physical health.

\section{Discussion and Conclusion}

Aiming at revealing the effect of mobbing on occupational burnout, this study was performed on 517 health staff. Cronbach alpha coefficients for Leymann Inventory and Maslach Inventory were 0.93 and 0.87, respectively. Soysal et al. (2014) reported reliability coefficient of Leymann Inventory performed on 200 health staff in Kilis, Turkey as 0.81 , for Maslach Inventory reliability coefficient was calculated as 0.83 in the study of Maslach and Jackson (1981) on human services professionals.

In this study, the mean score of mobbing of health staff was calculated as (1.75) lower than the middle level. Additionally, sub-dimension of mobbing with the highest mean score was obtained as "behavior threatening personal reputation" (rumoring, gossiping, slandering, holding up to ridicule etc.). In the study of Dikmetaş et al. (2011), the mean score of mobbing of assistant physicians working in a university hospital in Turkey (1.87) was obtained lower than the middle level as in our study. Avc1 and Kaya (2013) examined work related and non-work related outcomes of mobbing behaviours in service sector in Turkey, however, they obtained the sub-dimension with the highest mean score as "behavior threatening social contacts".

In the current study, the mean score of burnout of health staff was calculated as (2.49) lower than the middle level as well. And the sub-dimension which had the highest mean score was "emotional exhaustion". Similarly, Dikmetaş et al. (2011) in the study on assistant physicians working in a university hospital in Turkey obtained the sub-dimension of burnout having the highest mean score as "emotional exhaustion". Contrary to this result, examining the factorial validity of MBI on health nurses from west-central Florida, Beckstead (2002) found "reduced sense of personal accomplishment" as the sub-dimension with the highest mean score. Schaufeli and Van Dierendonck (1993), Poghosyan et al. (2009), and Adwan (2014) calculated the subdimension having the highest mean score as "personal accomplishment" in their studies on nurses. Similarly, in many studies conducted in other sectors, sub-dimension associated with accomplishment was determined as the one with the highest mean score (Maslach \& Jackson, 1981; Jackson \& Maslach, 1982; Wright \& Bonett, 1997; Rutherford et al., 2014; Sadeghi \& Khezrlou, 2014). That reduced sense of personal accomplishment is more than the feeling of emotional exhaustion in other countries with better working conditions may be due to ongoing working conditions more difficult in Turkey. In addition, emotional state of Turkish people can not be ignored undoubtedly.

This study revealed that the levels of mobbing and occupational burnout vary according to some personal characteristics. One of these findings was that the level of occupational burnout varies with respect to gender. Also, Maslach and Jackson (1981) found that there were differences between male and female for each of the MBI subscales. We identified that the level of female's occupational burnout is higher than the level of male's occupational burnout. This result may be caused by higher level of burnout in nurses (Schaufeli \& Van Dierendonck, 1993; Beckstead, 2002) and by a large amount of female nurses. However, the level of mobbing did not vary depending on gender. Furthermore, Quine (2001) reported that the level of mobbing in nurses does not vary in terms of gender, either. 
In the study, one of the important results was that the mobbing level of health staff varies according to marital status. Additionally, the levels of occupational burnout and mobbing of health staff that are single were found to be higher than married ones. Also, Ramirez et al. (1996) found that being single is an independent risk factor for a high emotional exhaustion score. One reason for this situation may be the work shift scheduling. Another reason is being given single employees more work considering that the responsibilities of single employees are less than married ones.

Although the levels of mobbing and occupational burnout of health staff vary depending on the variable "age", the difference was not statistically significant. Also, in the study of bullying in nurses, Quine (2001) determined that there was not a difference with regard to "age" variable. We found that both the levels of mobbing and occupational burnout of younger employees are higher than married ones. Maslach and Jackson (1981) reported that young employees have higher scores than old ones for depersonalization and emotional exhaustion subscales of MBI. We discovered that both the levels of mobbing and burnout of employees who are in the first five years of professional work are higher than the other groups. Adaptation problems, excessive workloads, lack of professional experience, tasks which are meaningless and do not belong to the employee's area of expertise can be given the reasons of this result.

In this study, a moderate positive correlation was found between mobbing and occupational burnout. According to the results of regression analysis, an increase in mobbing led to an increase in the value of 0.56 in occupational burnout. These results revealed that the basic hypothesis of this research (The frequency of mobbing behaviours in health staff has a crucial influence on the level of occupational burnout.) can be accepted. Restriction on communication, verbal attack on the person's way of performing job, physical attacks, social isolation, tease, gossip, employment with physically heavy tasks in the work places exhaust, depersonalize the victims and decrease their job satisfaction, and they do not feel efficient. Another important result of the research was that the most efficient sub-dimension is "behavior threatening personal reputation". This result can be explained as follows: the health staff has to undergo difficult intensive long-lasting education; however, in their professional life, they are faced with excessive workload, insufficient wages and even increasing violence. Thus, they complain about not receiving treatment they deserve and not having satisfactory living conditions. Under the influence of these problems, even a small attack of director increases the sensitivity of employees.

Mobbing behaviours at workplaces and occupational burnout have negative impacts on the working and private lives. Further research needs to be done to identify factors that influence mobbing and occupational burnout. Employees should be informed about mobbing and occupational burnout. Knowing their duties and rights, employees improve working environment and help to remove problems. 


\section{References}

Adwan, J. Z. (2014). Pediatric Nurses' Grief Experience, Burnout and Job Satisfaction. Journal of Pediatric Nursing, 29, 329-336.

Alkan, E., Yildız, S. M., \& Bakir, M. (2011). The effect of mobbing on burnout of physical education and sports teachers. Selçuk Üniversitesi Beden Ë̆itimi ve Spor Bilim Dergisi, 13(3), 270-280.

Avc1, U., \& Kaya, U. (2013). Yıldırma algısı ve etkileri: hizmet sektöründe bir araştırma. Ankara Üniversitesi SBF Dergisi, 68(02), 001-025.

Aydan, A., Mustafa, O., \& Tuna, S. (2012). Behaviors perceived as mobbing by the instructors assigned in special education institutions. Procedia-Social and Behavioral Sciences, 46, 4858-4863.

Beckstead, J. W. (2002). Confirmatory factor analysis of the Maslach Burnout Inventory among Florida nurses. International Journal of Nursing Studies, 39(8), 785-792.

Borritz, M., Rugulies, R., Bjorner, J. B., Villadsen, E., Mikkelsen, O. A., \& Kristensen, T. S. (2006). Burnout among employees in human service work: design and baseline findings of the PUMA study. Scandinavian Journal of Public Health, 34(1), 49-58.

Celep, C., \& Konakl1, T. (2013). Mobbing experiences of instructors: causes, results, and solution suggestions. Educational Sciences: Theory and Practice, 13(1), 193199.

Cogenli, M. Z., \& Barl1, O. (2013). The Exposure of Psychological Violence (Mobbing) in Universities and an Application to the Academicians. Procedia-Social and Behavioral Sciences, 93, 1174-1178.

Cornoiu, T. S., \& Gyorgy, M. (2013). Mobbing in Organizations. Benefits of Identifying the Phenomenon. Procedia-Social and Behavioral Sciences, 78, 708712.

Çobanoğlu, Ş. (2005). Mobbing işyerinde duygusal saldırı ve mücadele yöntemleri. İstanbul: Timaş Yayınları.

D'Alleo, G., \& Santangelo, A. (2011). Organizational climate and burnout in call-center operators. Procedia-Social and Behavioral Sciences, 30, 1608-1615.

Demirel, Y., \& Yoldaş, M. A. (2008). Sağlık kuruluşlarında karşılaşılan psikolojik yıldırma davranışlarının Türkiye ve Kazakistan açısından karşılaştırılması. Uluslararasi Insan Bilimleri Dergisi, 5(2), 1-25.

Dikmetaş, E., Top, M., \& Ergin, G. (2011). Asistan Hekimlerin Tükenmişlik ve Mobbing Düzeylerinin İncelenmesi [An Examination of Mobbing and Burnout of Residents]. Türk Psikiyatri Dergisi, 22(3), 137-149.

Einarsen, S., \& Hoel, H. (2001) The Negative Acts Questionnaire: Development, validation and revision of a measure of bullying at work. In 10th European congress on work and organisational psychology, Prague. 


\section{A. H. Türkan - İ. Kılıç 7/3 (2015) 7-21}

Einarsen, S., Matthiesen, S., \& Skogstad, A. (1998). Bullying, burnout, and well-being among assistant nurses. Journal of Occupational Health and Safety Australia and New Zealand, 14, 563-568.

Faria, J. R., Mixon, Jr. F. G., \& Salter, S. P. (2012). An economic model of workplace mobbing in academe. Economics of Education Review, 31, 720-726.

Heinemann, P. P. (1972). Mobbning: Gruppvåld bland barn och vuxna. Not Avail.

Hubert, A. B., \& Van Veldhoven, M. (2001). Risk sectors for undesirable behaviour and mobbing. European journal of work and organizational psychology, 10(4), 415424.

Jackson, S. E., \& Maslach, C. (1982). After-effects of job-related stress: Families as victim. Journal of Organizational Behavior, 3(1), 63-77.

Karakuş, M., \& Çankaya, İ. H. (2012). Examining a model related to mobbing incurred by Teachers. Hacettepe Üniversitesi Ĕgitim Fakültesi Dergisi (H. U. Journal of Education), 42, 225-237.

Kozak, A., Kersten, M., Schillmöller, Z., \& Nienhaus, A. (2013). Psychosocial workrelated predictors and consequences of personal burnout among staff working with people with intellectual disabilities. Research in Developmental Disabilities, $34,102-115$.

Laschinger, H. K. S., Wong, C. A., \& Grau, A. L. (2012). The influence of authentic leadership on newly graduated nurses' experiences of workplace bullying, burnout and retention outcomes: A cross-sectional study. International Journal of Nursing Studies, 49, 1266-1276.

Leymann, H. (1988). Ingen annan utväg: om utslagning och självmord som följd av mobbning i arbetslivet. Wahlström \& Widstrand.

Leymann, H. (1990). Mobbing and psychological terror at workplaces. Violence and Victims, 5(2), 119-126.

Leymann, H. (1996). The content and development of mobbing at work. European Journal of Work and Organizational Psychology, 5(2), 165-184.

Lorenz, K. (1991). Hier bin ich-wo bist Du? Ethologie der grauganz [Here I am-where are you? The behaviour of geese].

Maslach, C. (2003). Job Burnout: New Directions in Research and Intervention. Current Directions in Psychological Science, 12(5), 189-192.

Maslach, C., \& Jackson, S. E. (1981). The measurement of experienced burnout. Journal of Occupational Behaviour, 2, 99-113.

Naude, J. L. P., \& Rothmann, S. (2004). The validation of the Maslach Burnout Inventory-Human Services Survey for emergency medical technicians in Gauteng. SA Journal of Industrial Psychology, 30(3), 21-28.

NEA (National Education Association) (1965). Sampling and Statistics Handbook for Surveys in Education. National Education Association Press. Washington.

Poghosyan, L., Aiken, L. H., \& Sloane, D. M. (2009). Factor structure of the Maslach burnout inventory: An analysis of data from large scale cross-sectional surveys of 


\section{A. H. Türkan - İ. Kılıç 7/3 (2015) 7-21}

nurses from eight countries. International Journal of Nursing Studies, 46, 894902.

Quine, L. (2001). Workplace Bullying in Nurses. Journal of Health Psychology, 6(1), 73-84.

Ramirez, A. J., Graham, J., Richards, M. A., Gregory, W. M., \& Cull, A. (1996). Mental health of hospital consultants: the effects of stress and satisfaction at work. The Lancet, 347(9003), 724-728.

Rayner, C., \& Hoel, H. (1997). A Summary Review of Literature Relating to Workplace Bullying. Journal of Community \& Applied Social Psychology, 7, 181-191.

Rutherford, B. N., Shepherd, C. D., \& Tashchian, A. (2015). Validating the reduced burnout scale and sequencing of burnout. Journal of Business Research, 68, 6773.

Sadeghi, K., \& Khezrlou, S. (2014). Burnout among English Language Teachers in Iran: Do Socio-demographic Characteristics Matter? Procedia-Social and Behavioral Sciences, 98, 1590-1598.

Schaufeli, W. B., \& Van Dierendonck, D. (1993). The construct validity of two burnout measure. Journal of Organizational Behavior, 14(7), 631-647.

Solanelles, J. E., Carballeira, A. R., Benito, J. G., \& Zapf, D. (2010). Development and validation of the workplace bullying scale EAPA-T. International Journal of Clinical and Health Psychology, 10(3), 519-539.

Soysal, A., İnal, G., \& Gül, Z. (2014). Yıldırma (Mobbing) Davranışı: Sağlık Çalışanları Üzerinde Bir Araştırma. Selçuk Üniversitesi, İktisadi ve İdari Bilimler Fakültesi, Sosyal ve Ekonomik Araştırmalar Dergisi (The Journal of Social and Economic Research), 27.

Tanhan, F., \& Çam, Z. (2011). The relation between mobbing behaviors teachers in elementary schools are exposed to and their burnout levels. Procedia-Social and Behavioral Sciences, 15, 2704-2709.

Topa, G., \& Moriano, J. A. (2013). Stress and nurses' horizontal mobbing: Moderating effects of group identity and group support. Nursing Outlook, 61, e25-e31.

Vartia, M. A. L. (2001). Consequences of workplace bullying with respect to the wellbeing of its targets and the observers of bullying. Scandinavian journal of work, environment \& health, 27(1), 63-69.

Veldhoven, M. J. P. M., \& Meijman, T. F. (1994). Het meten van psychosociale arbeidsbelasting met een vragenlijst: de vragenlijst beleving en beoordeling van de arbeid (VBBA). Nederlands Instituut voor Arbeidsomstandigheden NIA.

Wright, T. A., \& Bonett, D. G. (1997). The Contribution of Burnout to Work Performance. Journal of Organizational Behavior, 18(5), 491-499.

Y1ldırım, H., \& Uysaloğlu, B. (2012). Impact of demographic factors on employees' perception of mobbing: A case study from a logistics company. Procedia-Social and Behavioral Sciences, 58, 634-644. 
A. H. Türkan - İ. Kılıç 7/3 (2015) 7-21

Zapf, D. (1999). Organisational, work group related and personal causes of mobbing/bullying at work. International Journal of Manpower, 20(1/2), 70-85.

Zapf, D., Knorz, C., \& Kulla, M. (1996). On the relationship between mobbing factors, and job content, social work environment, and health outcomes. European Journal of Work and Organizational Psychology, 5(2), 215-237. 